\title{
How bamboo influences the seed bank and biotic and abiotic factors of a Brazilian tropical forest
}

\author{
Débora Cristina Rother, ${ }^{1,}, 3 *$ (D), Paula Ponteli Costa ${ }^{4}$ (D), Thaís Diniz Silva² (1), Karinne Sampaio Valdemarin ${ }^{5}$ (1) \\ and Ricardo Ribeiro Rodrigues ${ }^{4}$ (1)
}

Received: November 5, 2019

Accepted: September 11, 2020

\begin{abstract}
There is a knowledge gap regarding the influence of bamboos on natural regeneration. This study evaluated how abundance, richness, dominance, evenness, diversity of the seed bank and biotic and abiotic factors (e.g., canopy opening, herbaceous cover, and litter thickness), differ between bamboo dominated (B) and non-dominated (NB) areas. The study was conducted in a fragment of Semideciduous Seasonal Forest surrounded by an agricultural landscape. Soil samples were taken at 20 points in each area at two time periods, to evaluate the seed bank. The results show that diversity and structural parameters of the seed bank differ between areas and time periods. There was higher abundance and richness of seedlings of herbaceous ruderal species in area B and a greater abundance of seedlings of arboreal species in area NB. Sampling points in the bamboo dominated area had greater canopy openings and greater cover by herbaceous species, facilitating the establishment of individuals belonging to the families Poaceae and Cyperaceae, which could have competitive advantages over other species of the regenerating community. Considering that bamboo can affect the seed bank, long-term studies are needed to understand successional dynamics and evaluate suitable management actions to conserve the diversity in remaining forests.
\end{abstract}

Keywords: Atlantic Forest, bamboo dominance, microhabitat, forest conservation, growth forms, plant community

\section{Introduction}

Disturbance-adapted species can affect forest dynamics and structure by facilitating or limiting the establishment of native individuals in the community (Simberloff \& Holle 1999; Mack et al. 2000; Michalet et al. 2006). A common competition issue is the relation between the natural regeneration process and the rapid growth of plants adapted to disturbance, such as bamboos (Campanello et al. 2007). With fast growth rates and clonal reproduction, bamboos rapidly spread through the forest competing for space and forming dense stands (Silveira 2005).

Bamboos present a life cycle that responds positively to natural (e.g., gaps, landslide, windy) or human-induced changes in the original community caused by logging and fire (Gadgil \& Prasad 1984; Balee 1989; Burman \& Filgueiras 1993; Nelson 1994), becoming dominant (Garrot et al. 1993). Bamboo-dominance in disturbed areas decreases light availability and negatively affects the germination, growth, and survival of native tree species (Tabarelli \& Mantovani 1999; Rother et al. 2013; Rother et al. 2016). Once established,

1 Departamento de Ecologia, Instituto de Biociências, Universidade de São Paulo, 05508-090, São Paulo, SP, Brazil

2 Departamento de Ciências Florestais, Escola Superior de Agricultura “Luiz de Queiroz”, Universidade de São Paulo, 13418-900,

Piracicaba, SP, Brazil

3 Centro de Ciências da Natureza, Universidade Federal de São Carlos, 18290-000, Buri, SP, Brazil

4 Departamento de Ciências Biológicas, Escola Superior de Agricultura “Luiz de Queiroz", Universidade de São Paulo, 13418-900,

Piracicaba, SP, Brazil

5 Departamento de Biologia Vegetal, Instituto de Biologia, Universidade Estadual de Campinas, 13083-862, Campinas, SP, Brazil

* Corresponding author: deborarother@gmail.com 
bamboo dominance limits the natural regeneration process (Oliveira-Filho et al. 1994; Carvalho 1997; Muler et al. 2014; Rother et al. 2013), reducing its plant richness (Tabarelli \& Mantovani 1999) or even arresting ecological succession, due to the high mortality of seedlings and saplings (Griscom \& Ashton 2003; Lima et al. 2012; Rother et al. 2013).

Over the past 20 years, the dynamics and structure of bamboo-dominated forests have been widely studied in some aspects. In general, studies have shown that gaps formed by bamboo death contribute to forest successional processes, creating suitable conditions for tree and shrub colonization of different successional groups that result in a heterogeneous plant composition (Martins et al. 2004; Santos et al. 2012; Santos et al. 2015; Capellesso et al. 2016). Other studies have focused on the effects of bamboo dominance over the composition and abundance of species by seed rain observation (Rother et al. 2009; GromboneGuaratini et al. 2014). Beyond the natural regeneration process, Lima et al. (2012) also analysed soil differences between bamboo-dominated and non-dominated areas in the Atlantic forest. Medeiros et al. (2013) pointed out the effect of bamboos on mortality, recruitment, and tree growth in the Amazon region. Several studies have aided knowledge about the structure and dynamics of forests dominated by bamboo. We, however, have a limited understanding of how bamboos influence the initial stages of the natural regeneration process (e.g., seed bank composition).

In certain remnant forests located in protected areas, bamboo dominance is considered one of the major factors reducing species richness (Lima et al. 2012). For that reason, understanding ecological processes involving the dynamics of the Atlantic forest, especially in bamboo-dominated areas, is necessary to adapt management and conservation actions in its remnants. Therefore, the present study aimed to: i) evaluate how abundance, richness, dominance, evenness, and diversity of seed bank species vary between periods and bamboo dominated and non-dominated areas, and ii) describe biotic and abiotic factors (canopy opening, herbaceous cover and litter thickness) in bamboo and non-bamboo dominated areas. Taking the pre-existing literature into consideration, we hypothesized that bamboo dominated areas would show marked differences in the diversity and structural parameters of the seed bank, when compared to non-bamboo dominated areas. We expect an abundant and less rich community, dominated by fewer species groups in bamboo dominated areas. Finally, we discussed the differences in biotic and abiotic factors between the two areas.

\section{Material and methods}

\section{Study area}

The study was conducted at Estação Experimental de Tupi, a protected area located in the rural region of Piracicaba municipality, São Paulo State, southeastern Brazil (Fig. 1). The area has 198 ha and is situated in the Semideciduous Seasonal Forest domain. The climate is classified as Cfa (Köppen), with mean annual precipitation of 1,280 $\mathrm{mm}$ and mean annual temperatures varying between 16.7 and 23. $3^{\circ} \mathrm{C}$ (Alvares et al. 2013).

Past land use of the area includes the cultivation of annual crops until 1949, followed by monoculture tree species plantation, as Pinus and Eucalyptus (Bovi 2013). Additionally, some areas were abandoned to induce the natural regeneration process; bamboos have occupied the gap areas while the regeneration was taking place. Now, the area is inserted in an agricultural landscape with the predominance of sugar cane. The forest fragment studied has approximately 3 ha, in which 2 ha are dominated by bamboo of the Merostachys genus. Non-bamboo area occupied approximately 1 ha and most of the sampling points were in the initial secondary stage of regeneration. The vegetation canopy corresponded to an average of $11.15 \mathrm{~m}$ height, while bamboo-dominated areas had about $9.25 \mathrm{~m}$ height during the data collection (authors pers. information).

\section{Data collection}

We conducted this study in one area of each situation (bamboo and non-bamboo) as the Estação Experimental de Tupi has no replicates of those situations (Tabs. S1, S2 in supplementary material). Twenty sampling points (evaluation units) of soil were randomly distributed at each area in two data collections: April 2013 and February 2014. The seed bank data was collected in two years, due to possible interannual changes in the seed production and dispersal process (Fig. 1).

\section{Seed bank}

Each sample had a soil volume of $3.125 \mathrm{~cm}^{3}(25 \times 25$ $\times 5 \mathrm{~cm}$ ), which was transferred to aluminum trays and conditioned in the seedling nursery of Escola Superior de Agricultura "Luiz de Queiroz", at the Universidade de São Paulo, Piracicaba in the State of São Paulo. The trays were monitored weekly to quantify and identify the plant growth of emergent seedlings of herbs, shrubs, and woody plants.

\section{Biotic and abiotic factors}

The biotic and abiotic factors were canopy opening, herbaceous cover, and litter thickness. They were obtained at the same 40 sampling points, 20 being in the bamboo dominated area and 20 in the non-bamboo dominated area. The canopy opening was estimated above each sampling point with a spherical densiometer (Lemmon 1957). Four densiometer readings were made facing outward at every side of each sampling point and averaged for analyses. These measurements were taken in the rainy season to avoid the plant deciduousness. The herbaceous cover was obtained by the percentage of soil covered by ground herbs (i.e., non-woody obligate species) (Lima \& Gandolfi 
2009). In the studied plots, herbs were mainly represented by grasses, no-woody vines, or herbs of the families Asteraceae, Begoniaceae, Cyperaceae and Commelinaceae. Measurements were taken in 20 plots of $1 \mathrm{~m}^{2}$ divided into four subplots in each area, and the average data was used for analyses. Litter thickness was obtained with a millimeter ruler range in the $1 \mathrm{~m}^{2}$ plots (Portela \& Santos 2007). Four measurements were made in each plot and the average was used for analyses.

\section{Data analysis}

For each area (bamboo dominated and non-dominated), the abundance, richness, dominance, evenness, and diversity of seedlings that emerged from the seed bank samples were quantified. Rarefied species richness was compared between bamboo and non-bamboo dominated areas by creating species accumulation curves with $95 \%$ confidence intervals derived from 1,000 permutations. Rarefaction curves were computed using the PAST program (Hammer et al. 2001). This comparison was made using counts of individuals per species, considering areas and data collections (Magurran 2004). The abundance and richness of seedlings obtained in each environmental sample were compared by using the non-parametric Kruskal-Wallis test. We also evaluated the diversity in seed banks per area by using the Shannon index. Shannon index was calculated using the natural logarithm. Diversity permutation test was used to evaluate differences in species diversity between bamboo and non-bamboo areas for both data collections (2013 and 2014). This analysis computes the Shannon index for two samples and then compares the diversities using random permutations. In the analysis, 9999 random matrices with two columns (data from bamboo and non-bamboo areas) were generated, each with the same row and column totals as in the original data matrix (Harper 1999). Evenness and dominance were calculated by the Pielou index (Magurran 2004) and compared between areas for both data collections by the Permutation test. The analysis was performed using the PAST program (Hammer et al. 2001).

To describe the biotic and abiotic factors (factors are used here to refer to the independent variables) of the bamboo and non-bamboo dominated areas, we first performed a Principal Component Analysis (PCA) to prevent collinearity between canopy opening, herbaceous cover, and litter thickness. This analysis computes the correlation for variables that are measured in different units. This implies normalizing the three variable values using division by their standard deviations. The eigenvalues give a measure of the variance accounted for by the corresponding eigenvectors (components). The percentages of variance accounted for these components are also given. According to the analysis, if most of the variance is accounted for in the first one or two components, the analysis scored successfully (Harper 1999; Hammer et al. 2001). To evaluate how much each variable varies between areas, we used a Mann-Whitney test. All analyses were performed using the PAST program (Hammer et al. 2001).
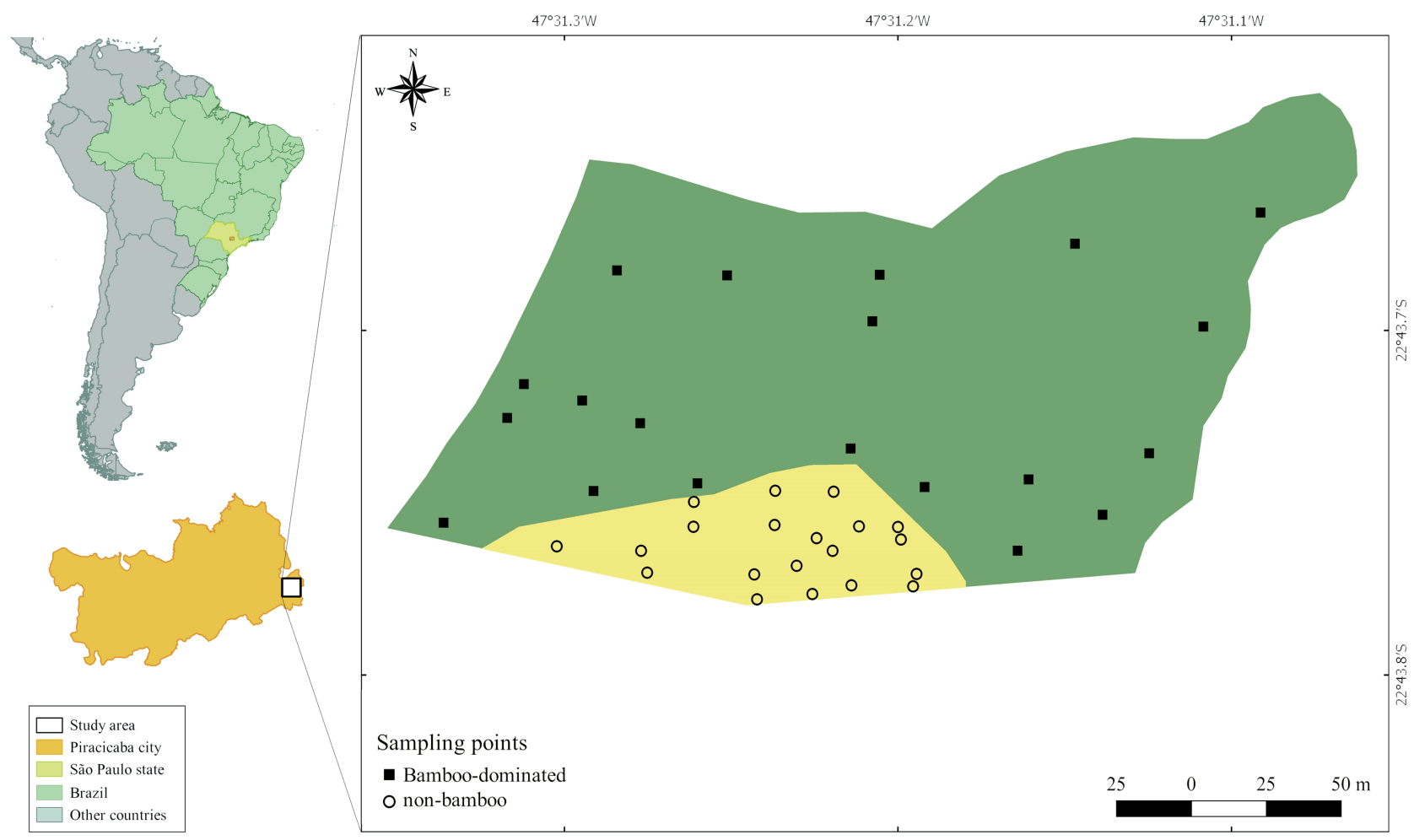

Figure 1. Sampling points in the forest fragment of Estação Experimental de Tupi, Piracicaba, São Paulo State, Brazil. 


\section{Results}

A total of 79 and 38 morphospecies were found in the first and second seed bank monitoring, respectively. Asteraceae was the richest family in both data collections. Species with the highest abundance of seedlings were Urochloa plantaginea and Cyperus esculentus, belonging to the families Poaceae and Cyperaceae, respectively, which also presented the greatest abundance, when compared to the other families. Among the species that emerged, only three presented arboreal growth form: Trema micrantha e (Cannabaceae), Croton floribundus (Euphorbiaceae) and Casearia sylvestris (Salicaceae). Seedlings of these species occurred in higher abundance in the non-bamboo sampling points.

The rarefaction curves for count data of individuals did not reach an asymptote for either bamboo or nonbamboo areas in both data collections (Fig. 2). Standardizing for the number of individuals, both areas showed higher species richness in the seed bank on the first data collection, showing marked interannual differences in seed production and dispersal process. A similar pattern was observed for abundance and richness. Values obtained for abundance and richness in the first data collection were significantly higher than those obtained in the second data collection (Tab. 1).

Comparing bamboo and non-bamboo dominated areas, no differences were found in species diversity $(p=0.08)$ for the first data collection (Tab. 2). The species diversity, however, varied significantly between areas in the second data collection, showing a higher diversity of seedlings in the sampling points without bamboos $(\mathrm{p}=0.0001)$ (Tab. 2). Dominance was higher for bamboo sampling points in both collections while evenness varied between areas in the second data collection. Evenness did not vary between areas in the first data collection, but sampling points in the non-bamboo dominated area revealed a more equal distribution of individuals among the species than sampling points located in the bamboo dominated area.

In the Principal Component Analysis (PCA), the first two axes represented $89.37 \%$ of the data variance. The eigenvalue obtained for axis 1 (1.74) can be considered high, while the low value for axis 2 indicates a short gradient and the influence of other biotic and abiotic factors in the ordination of the sampling points on this axis (Tab. 3). The canopy opening and herbaceous plant cover percentage correlated with the first ordination axis $(57.98 \%)$ and litter thickness with the second axis (31.40\%) (Fig. 3, Tab. 3). A restricted group of representative sampling points of the two areas is positively associated with canopy openness and soil cover by herbaceous plants. Another group of the nonbamboo area was positively associated with litter thickness, suggesting that these points show similar values for that variable (Fig. 3). Non-bamboo sampling points formed a small cohesive group in the PCA analysis, indicating a strong microhabitat similarity between them. For bamboodominated areas, however, we observed a group of dispersed

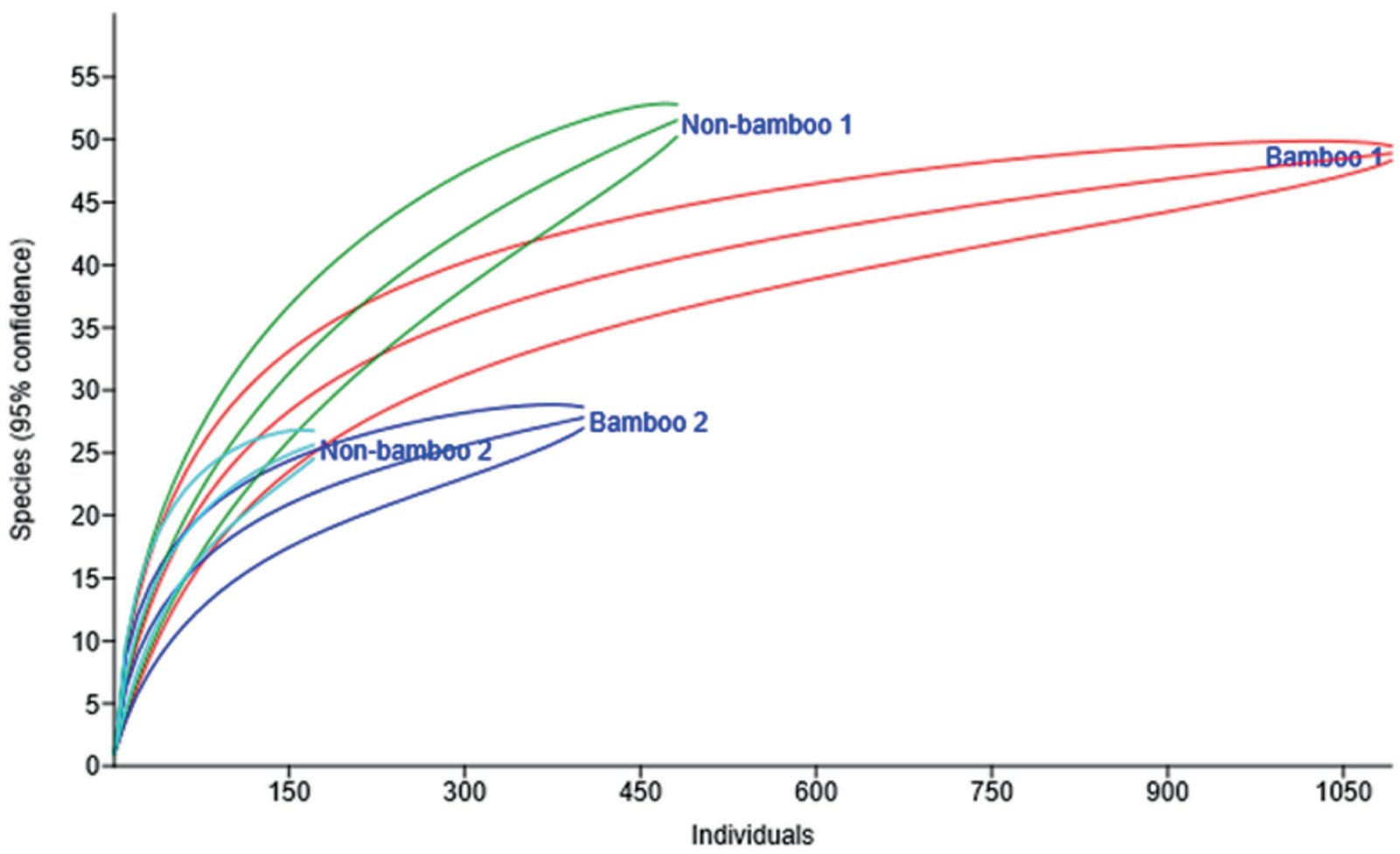

Figure 2. Rarefaction curves of the number of seedling species recorded in the seed bank of bamboo and non-bamboo dominated areas over the count of individuals of the study for both data collections. The envelopes represent the $95 \%$ confidence interval for 1,000 permutations. 
Table 1. Richness and abundance of the seed bank, seedlings in non-bamboo and bamboo-dominated areas for both data collections. Estação Experimental de Tupi, Piracicaba, São Paulo State, Brazil.

\begin{tabular}{|c|c|c|c|c|}
\hline \multirow{2}{*}{ Parameters } & \multicolumn{2}{|c|}{ Non-bamboo } & \multicolumn{2}{|c|}{ Bamboo-dominated } \\
\cline { 2 - 5 } & Data Collection 1 & Data Collection 2 & Data Collection 1 & Data Collection 2 \\
\hline Richness & 53 & 26 & 49 & $28^{*}$ \\
\hline Abundance (number of individuals) & 493 & 183 & $1100^{*}$ & $411 *$ \\
\hline
\end{tabular}

* indicates differences between areas in the same data collection.

Table 2. Diversity index (Shannon), dominance, and the Pielou evenness of the seed bank seedlings in non-bamboo and bamboodominated areas for the two data collections. Estação Experimental de Tupi, Piracicaba, São Paulo State, Brazil.

\begin{tabular}{|c|c|c|c|c|}
\hline \multirow{2}{*}{ Parameters } & \multicolumn{2}{|c|}{ Non-bamboo } & \multicolumn{3}{|c|}{ Bamboo-dominated } \\
\cline { 2 - 5 } & Data Collection 1 & Data Collection 2 & Data Collection 1 & Data Collection 2 \\
\hline Dominance & 0.13 & 0.12 & $0.18^{*}$ & $0.16^{*}$ \\
\hline Shannon (H') & 2.72 & 2.63 & 2.54 & $2.33^{*}$ \\
\hline Pielou Evenness (J) & 0.69 & 0.81 & 0.65 & $0.70 *$ \\
\hline
\end{tabular}

* indicates differences between areas in the same data collection.

Table 3. Eigenvalues and percent variance for the first three ordination axes of Principal Component Analysis (PCA).

\begin{tabular}{|c|c|c|}
\hline Axes & Eigenvalues & \% of variance \\
\hline 1 & 1.74 & 57.98 \\
\hline 2 & 0.94 & 31.40 \\
\hline
\end{tabular}

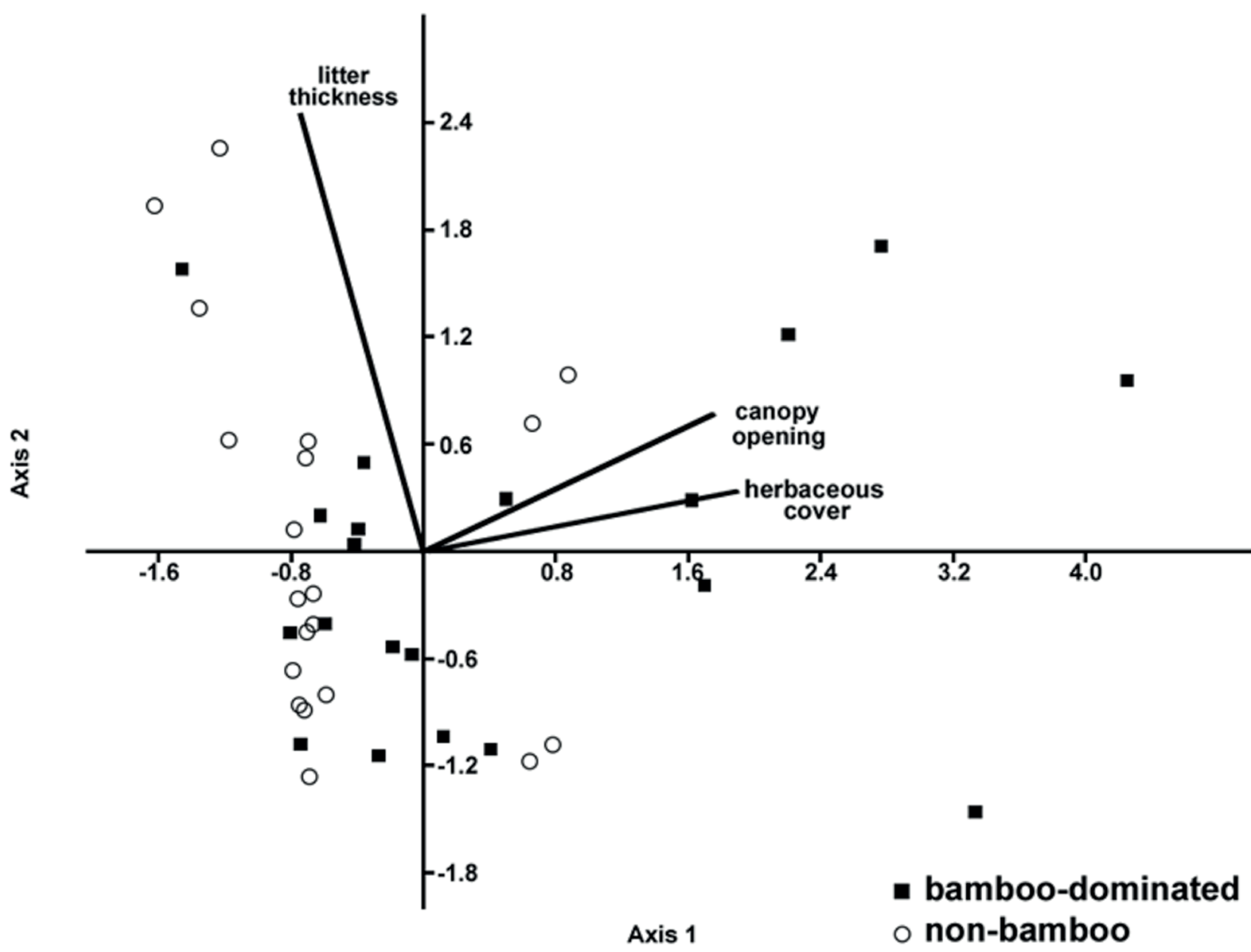

Figure 3. Diagram of the first two axes (axis 1-horizontal and axis-2-axis) of the Principal Component Analysis (PCA), according to the canopy opening, herbaceous cover, and litter thickness in non-bamboo and bamboo-dominated areas. The vectors of the variables represent the magnitude and the direction of the variations. 
points resulting in a greater variation of the three biotic and abiotic factors studied (Fig. 4A-B).

The canopy was more open $(\mathrm{U}=105.5, \mathrm{p}=0.0107, \mathrm{n}$ $=20)$ and the herbaceous cover was higher in bamboodominated areas $(\mathrm{U}=111.5 ; \mathrm{p}=0.0161 ; \mathrm{n}=20)$ (Fig. 5A-B, respectively). Litter thickness did not vary between areas $(\mathrm{U}=165 ; \mathrm{p}=0.3493 ; \mathrm{n}=20)($ Tab. 4).

\section{Discussion}

Bamboo dominated areas showed marked shifts in the early regeneration of the forest fragment studied, as shown by the changes in seed bank composition, richness, dominance, and the evenness, especially for the second period. As expected, sampling points in the bamboodominated areas showed higher seedling abundance for both periods and, interestingly, higher evenness resulted from the dominance of herbaceous ruderal species, predominantly from Poaceae ( $41 \%$ of the total seedlings) and Cyperaceae (23\% of the total seedlings). Cyperus esculentus (first collection) and Urochloa plantaginea (second collection) dominated the community in the bamboo dominated area. These species are dependent on high solar radiation to germinate and establish in the area (Lorenzi 2006; Moreira $\&$ Bragança 2010). The lower canopy cover in most sampling
A

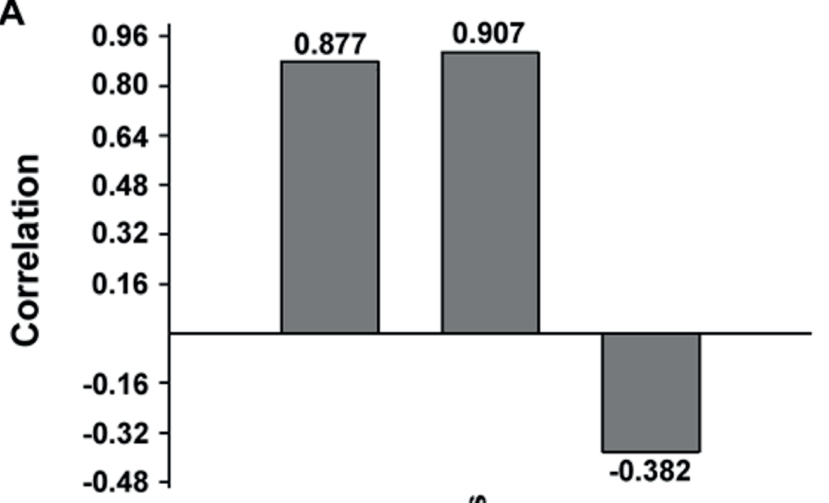

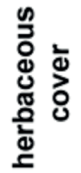

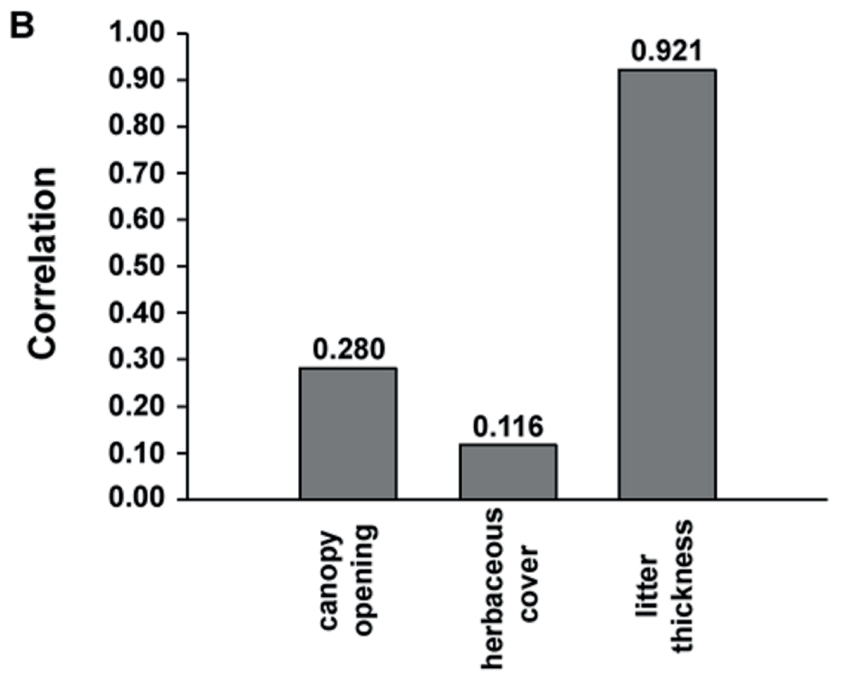

Figure 4. Eigenvectors of the first two ordination axes resulting from the Principal Component Analysis (PCA) for the canopy opening, herbaceous cover, and litter thickness. We observed the correlation of biotic and abiotic factors with axis 1 in $\mathbf{A}$ and axis 2 in $\mathbf{B}$.

A

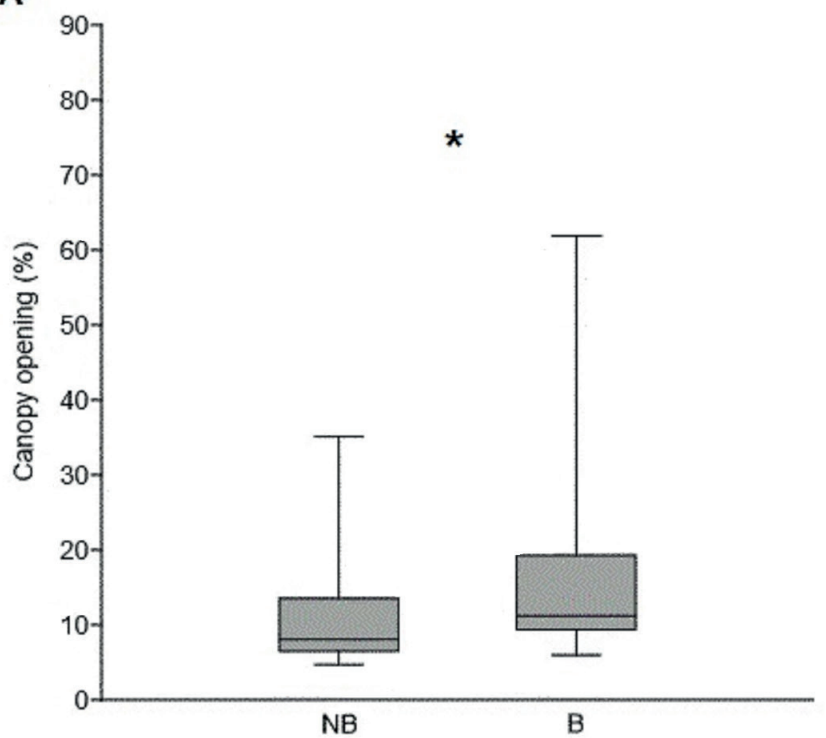

B

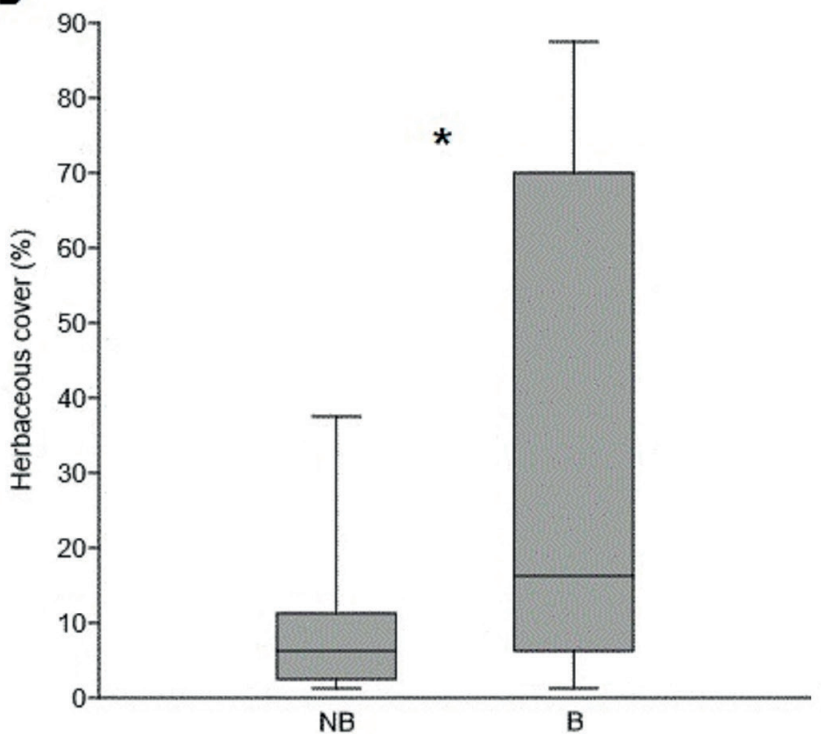

Figure 5. Biotic and abiotic factors (canopy opening and herbaceous cover) (A) in non-bamboo (NB) and bamboo dominated (B) areas in the forest fragment of Estação Experimental de Tupi, Piracicaba, São Paulo State, Brazil. The upper and lower border of the box are the 75th and 25th percentiles, respectively; the black horizontal line within the box is the median and the error bars are the 10th and 90th percentiles. $\left.{ }^{*}\right)$ Significant differences between bamboo and non-bamboo dominated areas $(\mathrm{p} \leq 0.05)$. 
Table 4. Biotic and abiotic factors (canopy opening, herbaceous coverage and litter thickness) in non-bamboo and bamboo-dominated areas. Estação Experimental de Tupi, Piracicaba, São Paulo State, Brazil.

\begin{tabular}{|c|c|c|c|}
\hline Area & Canopy opening $(\%) \pm$ SE & Herbaceous cover $(\%) \pm$ SE & Litter thickness $(\mathbf{c m}) \pm$ SE \\
\hline Non-bamboo & $11.82 \pm 1.94$ & $9.13 \pm 1.96$ & $4.04 \pm 0.31$ \\
\hline Bamboo-dominated & $18.70 \pm 3.34$ & $32.25 \pm 7.10$ & $3.54 \pm 0.25$ \\
\hline p-value & $\leq 0.05^{*}$ & $\leq 0.05^{*}$ & $\geq 0.05$ \\
\hline
\end{tabular}

$\mathrm{SE}=$ standard error

*Significant values

points of the bamboo- dominated areas may have stimulated the arrival by dispersal of such pioneer species in the seed bank. In contrast, sampling points in the non-bamboo area showed a greater abundance of seedlings of tree species such as $C$. floribundus, T. micrantha, and C. sylvestris. These species are pioneers in the succession process, heliophilous, fastgrowing, and responsible for the rapid canopy closure after clearing openings in the forest (Nascimento et al. 1999; Paula et al. 2004). In degraded areas, edges or gaps, the dominance of one or a few tree species with similar ecological behaviour in the seed bank is common, corroborating the dominance of early colonizing tree species in disturbed forests similar to the non-bamboo dominated area (Tabarelli et al. 2008; Melo et al. 2013).

The absence of similar situations to replicate the data collection-imposed limitations for extrapolating our results to a wider population. However, some discussions of general patterns regarding the biotic and abiotic characteristics in the sampling points can be mentioned. The difference found in seed bank species composition and richness between both areas may be explained by the within-site heterogeneity of the studied areas. Biotic and abiotic factors can influence seed germination and generate differential species establishment rate (Vazquez-Yanes \& Orozco-Segovia 1993; Rother et al. 2016). The understanding of which factors influence seedling establishment in bamboo and non-bamboo dominated areas still needs to be deeply investigated (Rother et al. 2016). It is possible, that some variables such as light and soil cover by herbaceous plants can affect the recruitment pattern of species in the forest, structuring the plant community (Vazquez-Yanes \& Orozco-Segovia 1993; Lima \& Gandolfi 2009; Rother et al. 2016). Light availability is known to be an important factor for breaking seed dormancy and for growth in tropical plants (Howe et al. 1985), while soil cover by herbaceous plants can influence patterns of seed predation or germination of woody seedlings (Schupp 1988; Lima \& Gandolfi 2009). Sampling points in the bamboo-dominated area are characterized by a lower and discontinuous canopy, enhancing the light entrance to the forest ground. Great herbaceous cover and low litter thickness, in comparison with sampling points in the non-bamboo dominated area, were also found by Rother et al. (2016) in a tropical forest. The more closed canopy observed in the non-bamboo area may have functioned as a barrier preventing light from reaching the forest ground, directly affecting the ruderal herbaceous germination and its establishment (Yates et al.
2004). Nevertheless, forest conditions in the non-bamboo area have favoured the establishment of native tree species, as found in previous studies (Griscom \& Ashton 2003; Griscom et al. 2007; Rother et al. 2016).

Although not evaluated, the land surrounding the Estação Experimental de Tupi can exert some influence on the bamboo and non-bamboo dominated areas. The matrix around the studied area can be a source of intense disturbances, such as fire, pesticide drift, and cattle entrance. The matrix can also contribute to the seed dispersal of ruderal herbaceous species from the adjacent pasturelands (Bierregaard 1992; Laurence 1997), which showed a great abundance of seedlings emerged from the seed bank. The edge effect causes drastic changes in the abiotic characteristics of the microhabitat, such as increased soil and air temperature, reduction in relative air and soil humidity, and increased light intensity and wind speed influencing the recruitment of several forest species (Tomimatsu \& Ohara 2004; Yates et al. 2004). The distribution of some bamboo spots coincides with the edge of the forest fragment favouring the high occurrence and abundance of ruderal herbaceous species in such areas. This pattern was not observed in the sampling points located in the non-bamboo area which may be due to the larger shaded areas found in such points and the dispersal of native species propagules within the forest fragment. It is evident that more studies focusing on the effects of the local and landscape factors are needed to fill this knowledge gap.

Vinha et al. (2011), analysing the seed bank of Parque Estadual das Fontes do Ipiranga in São Paulo State, found that even in areas dominated by bamboo Aulonemia aristulata, the seed bank is still viable and composed mostly by native species. Rother et al. (2009), however, studying in the Parque Estadual Carlos Botelho in São Paulo State, found a composition of the seed rain quantitatively different between the sites with and without bamboo Guadua tagoara, suggesting that the presence of bamboo influences the composition of the future plant community. Those bamboos are working as a demographic bottleneck that acts selectively in the plant regeneration cycle (Rother et al. 2016). A similar pattern can be seen in our studied area when the differences in the composition, diversity, and structural parameters of the seed bank are considered. The bamboo dominated area of Estação Experimental de Tupi may have its natural regeneration processes compromised by the competition between bamboo and non-bamboo species; moreover, the 
anthropogenic disturbances coming from the agricultural surrounding matrix and the invasion of ruderal herbaceous species can also alter the natural regeneration dynamics (Matos \& Pivello 2009). These factors may result in the limitation of the tree species recruitment and the future canopy closure (Laurence 1997; Tomimatsu \& Ohara 2004).

The studied forest fragment is small and isolated in the landscape, common characteristics of most Atlantic Forest remnants (Ribeiro et al. 2009). These conditions require management actions aiming for biodiversity conservation (Gunderson 2000; Vidal et al. 2016). Management actions include the elimination of degradation factors, in this case, the removal of the anthropogenic disturbances of the surrounding matrix and the experimental Merostachys sp. control. Actions such as enrichment with native species or functional groups that have become locally rare, absent, or in low abundance may be implemented to avoid losses of biodiversity (Leão et al. 2014; Rodrigues et al. 2011). Other elements such as soil integrity, the presence of seed bank and the structural and functional connection via restoration with areas that would be sources of propagules, can also define the success of management actions and should be addressed during the planning (Norden et al. 2009; Rother et al. 2013; Rother et al. 2019).

Our results emphasize that the presence of bamboos selectively influences the seed bank, consequently changing the regeneration dynamic of the fragment, due to potential shifts in forest structure. In the bamboo dominated area, there is a more open canopy and a greater cover by herbaceous species, which facilitates the establishment of species with competitive advantages over other species of the regenerating community. Long-term studies are necessary to evaluate the successional dynamics as well as studies that evaluate management actions (e.g., removal of bamboos in experimental plots to evaluate seedling establishment) to conserve the plant diversity in the threatened Atlantic forest.

\section{Acknowledgements}

We are very grateful to the Instituto Florestal for the permission to carry out the data collection in the Estação Experimental de Tupi and to Escola Superior de Agricultura "Luiz de Queiroz" for its infrastructure and valuable technical support on this project. This work was financially supported by São Paulo Research Foundation (FAPESP) (\#2013/507185) granted to RRR. PPC was supported by CNPQ and DCR received a research grant and fellowship from the São Paulo Research Foundation (FAPESP) (\#2012/24118-8).

\section{References}

Alvares CA, Stape JL, Sentelhas PC, Gonçalves JLM, Sparovek G. 2013. Köppen's climate classification map for Brazil. Meteorologische Zeitschrift 22: 711-728.
Balée W. 1989. The culture of Amazonian forests. Advances in Economic Botany 7: 1-21.

Bierregaard RO, Lovejoy TE, Kapos V, Santos AA, Hutchings RW. 1992. The biological dynamics of tropical rainforest fragments. Bioscience 42: 859-866.

Bovi RC. 2013. Avaliação espacial e temporal de processos erosivos e dendrogeomorfologia em um fragmento de Mata Atlântica em Piracicaba - SP. MSc Thesis, Universidade de São Paulo, Piracicaba.

Burman AG, Filgueiras T. 1993. A review of the woody bamboo genera of Brazil (Gramineae: Bambusoideae: Bambuseae). Thaiszia 3: 53-88.

Campanello PI, Gatti MG, Ares A, Montti L, Goldstein G. 2007. Tree regeneration and microclimate in a liana and bamboo-dominated semideciduous Atlantic forest. Forest Ecology and Management 252: 108-117.

Capellesso ES, Weirich R, Dariva G, Sausen TL, Zanin EM. 2016. Influence of bamboo dieback on arboreal diversity in a subtropical forest fragment. Revista Chilena de História Natural 89: 1-6.

Carvalho LMT. 1997. Dinâmica de clareiras em uma floresta de nuvem na Serra do Ibitipoca, Minas Gerais. MSc Thesis, Universidade Federal de Lavras, Lavras

Gadgil M, Prasad SN. 1984. Ecological determinants of life history evolution of two Indian bamboo species. Biotropica 16: 161-172.

Garrot RA, White PJ, White CAV. 1993. Overabundance: an issue for conservation biologists? Conservation Biology 7: 946-949.

Griscom BW, Ashton PM. 2003. Bamboo control of forest succession: Guadua sarcocarpa in Southeastern Peru. Forest Ecology and Management 175: 445-454.

Griscom BW, Daly DC, Ashton MS. 2007. Floristics of bamboo-dominated stands in lowland terra-firme forests of southwestern Amazonia. Journal of Torrey Botanical Society 134: 108-125.

Grombone-Guaratini MT, Alves LF, Vinha D, Franco GADC. 2014. Seed rain in areas with and without bamboo dominance within an urban fragment of the Atlantic Forest. Acta Botanica Brasilica 28: 76-85.

Gunderson LH. 2000. Ecological resilience - in theory and application. Annual Review of Ecology and Systematics 31: 425-439.

Hammer O, Harper DAT, Ryan PD. 2001. PAST: Paleontological Statistics Software Package for Education and Data Analysis. Palaeontologia Electronica 4: 9. https://paleo.carleton.ca/2001_1/past/past.pdf.

Harper DA. 1999. Numerical paleobiology: computer-based modelling and analysis of fossils and their distributions. New York, John Wiley \& Sons Inc.

Howe HF, Schupp EW, Westley LC. 1985. Early consequences of seed dispersal for a neotropical tree (Virola surinamensis). Ecology 66: 781-791.

Laurence WF. 1997. Hyper-disturbed parks: edge effects and the ecology of isolated rainforest reserves in tropical Australia. In: Laurence WF, Bierregard RO. (eds.) Tropical forest remnants: ecology, management and conservation of fragmented communities. Chicago, University of Chicago Press. p. 71-83.

Leão TCC, Fonseca CR, Peres CA. 2014. Predicting extinction risk of Brazilian Atlantic Forest Angiosperms. Conservation Biology 28: 1349-1359.

Lima RAF, Gandolfi S. 2009. Structure of the herb stratum under different light regimes in the Submontane Atlantic Rain Forest. Brazilian Journal of Biology 69: 631-637.

Lima RAF, Rother DC, Muler AE, Lepsch IF, Rodrigues RR. 2012. Bamboo overabundance alters forest structure and dynamics in the Atlantic Forest hotspot. Biological Conservation 147: 32-39.

Lorenzi H. 2006. Manual de identificação e controle de plantas daninhas: plantio direto e convencional. 6th. edn. Nova Odessa, Instituto Plantarum.

Mack RN, Simberloff D, Lonsdale WM, Evans H, Clout M, Bazzaz FA. 2000. Biotic invasions: causes, epidemiology, global consequences, and control. Ecological Applications 10: 689-710.

Magurran AE. 2004. Measuring biological diversity. Oxford, Blackwell Science.

Martins SV, Colletti Júnior R, Rodrigues RR, Gandolfi S. 2004. Colonization of gaps produced by death of bamboo clumps in a semideciduous mesophytic forest in South-eastern Brazil. Plant Ecology 172: 121-131. 
Matos DMS, Pivello VR. 2009. O impacto das plantas invasoras nos recursos naturais de ambientes terrestres: alguns casos brasileiros. Ciência e Cultura 61: 27-30

Medeiros H, Castro W, Salimon CI, Silva IB, Silveira M. 2013. Tree mortality, recruitment and growth in a bamboo dominated forest fragment in southwestern Amazonia, Brazil. Biota Neotropica 13: 29-34.

Melo FPL, Arroyo-Rodríguez V, Fahrig L, Martínez-Ramos M, Tabarelli M. 2013. On the hope for biodiversity-friendly tropical landscapes. Trends in Ecology and Evolution 28: 461-468.

Michalet R, Brooker RW, Cavieres LA, et al. 2006. Do biotic interactions shape both sides of the humped-back model of species richness in plant communities? Ecology Letters 9: 767-773.

Moreira HJC, Bragança HBN. 2010. Manual de Identificação de Plantas Infestantes. Cultivos de verão. Campinas, São Paulo.

Muler AE, Rother DC, Brancalion PHS, Naves RP, Rodrigues RR, Pizo MA. 2014. Can overharvesting of a non-timber-forest-product change the regeneration dynamics of a tropical rainforest? The case study of Euterpe edulis. Forest Ecology and Management 324: 117-125.

Nascimento HEM, Dias AS, Tabanez AAJ, Viana VM. 1999. Estrutura e dinâmica de populações arbóreas de um fragmento de Floresta Estacional Semidecidual na região de Piracicaba, SP. Revista Brasileira de Biologia 59: 329-342.

Nelson BW. 1994. Natural forest disturbance and change in the Brazilian Amazon. Remote Sensing Review 10: 105-125.

Norden N, Chazdon RL, Chao A. 2009. Resilience of tropical rain forests: tree community reassembly in secondary forests. Ecology Letters 12: 385-394.

Oliveira-Filho AT, Vilela EA, Gavilanes ML, Carvalho DA. 1994. Effect of flooding regime and understorey bamboos on the physiognomy and tree species composition of a tropical semideciduous forest in southeastern Brazil. Plant Ecology 113: 99-124.

Paula A, Silva AF, Marco Júnior P, Santos FAM, Souza AL. 2004. Sucessão ecológica da vegetação arbórea em uma Floresta Estacional Semidecidual, Viçosa, MG, Brasil. Acta Botanica Brasilica 18: 407-423.

Portela RCQ, Santos FAM. 2007. Produção e espessura da serapilheira na borda e interior de fragmentos florestais de Mata Atlântica de diferentes tamanhos. Revista Brasileira de Botânica 30: 271-280.

Ribeiro MC, Metzger JP, Martensen AA, Ponzoni FJ, Hirota MM. 2009. The Brazilian Atlantic Forest: how much is left, and how is the remaining forest distributed? Implications for conservation. Biological Conservation 142: 1141-1153.

Rodrigues RR, Gandolfi S, Nave AG. 2011. Large-scale ecological restoration of high-diversity tropical forests in SE Brazil. Forest Ecology and Management 261: 1605-1613.

Rother DC, Jordano P, Rodrigues RR. 2013. Demographic bottlenecks in tropical plant regeneration: A comparative analysis of causal influences. Perspectives in Plant Ecology, Evolution and Systematics 15: 86-96.
Rother DC, Liboni AP, Magnago LF, Chao A, Chazdon RL, Rodrigues RR. 2019. Ecological restoration increases conservation of taxonomic and functional beta diversity of woody plants in a tropical fragmented landscape. Forest Ecology and Management 451: 117538. doi: 10.1016/j.foreco.2019.117538

Rother DC, Rodrigues RR, Pizo MA. 2009. Effects of bamboo stands on seed rain and seed limitation in a rainforest. Forest Ecology and Management 257: 885-892.

Rother DC, Rodrigues RR, Pizo MA. 2016. Bamboo thickets alter the demographic structure of Euterpe edulis population: A keystone, threatened palm species of the Atlantic forest. Acta Oecologica 70: 96-102.

Santos KF, Ferreira TS, Higuchi P, et al. 2015. Regeneração natural do componente arbóreo após a mortalidade de um maciço de taquara em um fragmento de Floresta Ombrófila Mista em Lages - SC. Ciência Florestal 25: 107-117.

Santos SC, Budke JC, Muller A. 2012. Regeneração de espécies arbóreas sob a influência de Merostachys multiramea Hack. (Poaceae) em uma floresta subtropical. Acta Botanica Brasilica 26: 218-229.

Schupp EW. 1988. Factors affecting post dispersal seed survival in a tropical forest. Oecologia 76: 525-530.

Silveira M. 2005. A floresta aberta com bambu no sudoeste da Amazônia: padrões e processos em múltiplas escalas. PhD Thesis, Universidade de Brasília, Rio Branco.

Simberloff D, Holle B. 1999. Positive interactions of nonindigenous species: invasional meltdown? Biological Invasions 1: 21-32.

Tabarelli M, Lopes AV, Peres CA. 2008. Edge-effects drive forest fragments towards an early-successional system. Biotropica 40: 657-661.

Tabarelli M, Mantovani W. 1999. Clareiras naturais e a riqueza de espécies pioneiras em uma floresta Atlântica montana. Revista Brasileira de Biologia 59: 251-261.

Tomimatsu H, Ohara M. 2004. Edge effects on recruitment of Trillium camschatcense in small forest fragments. Biological Conservation 177: 509-519.

Vázquez-Yanes C, Orozco-Segovia A. 1993. Patterns of seed longevity and germination in the tropical rainforest. Annual Review of Ecology and Systematics 24: 69-87.

Vidal CY, Mangueira JR, Farah FT, Rother DC. 2016. Biodiversity conservation of forests and their ecological restoration in highly modified landscapes. In: Gheler-Costa C, Lyra-Jorge MC, Verdade LM. (eds.) Biodiversity in agricultural landscapes of southeastern Brazil. Berlin, De Gruyter Open Ltd. p. 136-150.

Vinha D, Alves LF, Zaidan LBP, Grombone-Guaratini MT. 2011. The potential of the soil seed bank for the regeneration of a tropical urban forest dominated by bamboo. Landscape and Urban Planning 99: 178-185.

Yates ED, Levia-Junior DF, Wiliams CL. 2004. Recruitment of three nonnative plants into a fragments forest in Southern Illinois. Forest Ecology and Management 190: 119-130. 